\title{
MEDIATION AS ALTERNATIVE DISPUTE RESOLUTION: LEGAL ANALYSIS, FOREIGN PRACTICE, AND PERSPECTIVES IN RUSSIA Lilia A. Sungatullina ${ }^{1 *}$, Robert R. Izmailov², Andrey V. Mikhaylov ${ }^{3}$ \\ ${ }^{1,2,3}$ Kazan Federal University, Russia. \\ Email: 1*1ilia.sungatullina@mail.ru, 2izmailov.robert@mail.ru, ${ }^{3}$ avm@pravmail.ru
}

Article History: Received on $12^{\text {th }}$ October 2019, Revised on $29^{\text {th }}$ November 2019, Published on $19^{\text {th }}$ December 2019

\begin{abstract}
Purposes: The article is devoted to the analysis of legal problems of mediation as an alternative way to resolve disputes. The article examines the Russian and foreign experience in the legal regulation of mediation.

Methodology: The use and adaptation of foreign experience in applying the mediation procedure are aimed at increasing the speed of dispute resolution, the level of confidentiality and the ability to maintain partnerships. The authors suggest ways to improve the effectiveness and applicability of this procedure in practice. According to Sungatullina L.A., it seems efficient and promising to use alternative methods for resolving disputes in general and to apply the mediation procedure in particular. Izmailov R.R. He believes that the experience of using mediation techniques has shown its effectiveness in resolving various categories of disputes: labor, family, corporate, business conflicts, as well as in the field of housing relations. Mikhailov A.V. notes that the effectiveness of the mediation process largely depends on the implementation at all stages of the basic principles.
\end{abstract}

Results: The authors conclude that it is advisable to apply mediation to disputes arising from administrative and other public relations. As one of the ways to improve the legislative regulation of mediation, it is proposed to consider the possibility of introducing a notarial certification of mediation agreements.

Implications/Applications: Alternative dispute resolution is a set of procedures that facilitate non-judicial dispute resolution. In English practice, it is indicated by the steady turnover of Alternative dispute resolution (hereinafter ADR). Different non-judicial forms of resolution of a case are referred to ADR in different countries. As a rule, three well-known forms are called: arbitration, mediation, and negotiations.

Novelty/Originality: The novelty of this study in classifying the mediation techniques.

Keywords: Mediation, Alternative Dispute Resolution, Conflict Resolution, Conciliation Procedures, Business Law, Legal Problems.

\section{INTRODUCTION}

The life of every person consists of a series of decisions. We constantly make choices, sometimes without even noticing it, but it is the choice that determines what our life will be like in the next minute, month, year, decade ... It sometimes happens that a choice leads to controversial, possibly even conflict, situations. In fact, any social interactions, defending one's own interests and rights can lead to conflicts and disputes. There are various methods of dealing with conflict situations. So, the conflict can be resolved both with the help of the judicial system and without resorting to the help of the judiciary. You can try to resolve the dispute even through the use of force. However, the most promising from the point of view of a progressive society is, to date, the use of so-called alternative methods of resolving (resolving) disputes, which, of course, include mediation.

\section{METHODS}

The methodological basis of the work is a set of scientific techniques and methods for studying phenomena and processes, including methods of analysis, synthesis, comparative law, as well as a formal legal method. The use of the proposed methods seems appropriate for several reasons. The formal legal method allows, on the basis of legislation, to formulate a conceptual framework applicable to the study, to identify the signs and characteristics of the institution in question. The comparative legal method takes a significant place in the work and allows you to explore the possibility of implementing foreign experience in legal regulation.

\section{RESULTS AND DISCUSSION}

In the US, there are 22 forms of non-judicial dispute resolution (Types of Dispute Resolution Processes, 2019), and in England, experts identify from 5 to 8 forms. Two types of ADR are common in France: mediation and reconciliation. Moreover, mediation and reconciliation can be both extrajudicial and judicial (Cadiet, 2011). In Germany, on July 26, 2012, the Law on Mediation and Other Forms of Out-of-Court Settlement of Conflicts was adopted, according to which mediation is the main out-of-court method for resolving disputes (Abolonin, 2103). Within the framework of the Eurasian Economic Commission, there is a separate department that develops principles, methods, rules, mechanisms, as well as forms a regulatory framework for resolving disputes (mediation) in the Eurasian Economic.

In Russia today, perhaps the most common way to protect your interests is through state judicial protection. However, the choice of this path may entail unpleasant consequences. It's not a secret for anyone that the judicial system is 
imperfect, litigation can last for years, the decision made can be unpredictable and not suit any of the parties to the dispute, in addition, open processes and free access to the bank of court decisions make the dispute public. In addition, after lengthy and energy-intensive processes, the conflicting parties are unlikely to maintain good partnerships.

In the Russian Federation, the mediation procedure is regulated by the special law adopted in 2010 "On an alternative dispute resolution procedure with the participation of a mediator (mediation procedure)". Mediation is an effective way to resolve disputes involving an independent person (mediator). This is a special form of mediation that does not imply a third party makes a decision on the dispute. The main task of the mediator is to assist the parties in making a mutually acceptable and viable solution. According to the Mediation Act 2010, mediation is a method of resolving disputes with the assistance of a mediator on the basis of the voluntary consent of the parties in order to reach a mutually acceptable solution.

Types of mediation can be classified on the following grounds:

- By areas (business disputes, family mediation, labor disputes);

- Ecosystem approach (applies in family disputes, conventions are used);

- Cross-border mediation (when the participant is a foreign company, or there is a guest marriage, the mediators are in different countries, preparing a meeting of the parties);

- Directive mediation (when the mediator leads the parties behind him and puts the other side in his place);

- Narrative mediation (taking into account the history of relationships, the purpose of mediation is to remind the parties about good events);

- Restorative mediation (restorative reconciliation when there are a victim and a criminal) (Besemer, 2009).

According to Part 2, 3 and 5 of Art. 1 of the Law on Mediation, with its help disputes arising from civil legal relations can be resolved, including in connection with entrepreneurial and other economic activities, family and labor relations, as well as in other cases provided for by federal laws, with the exception of collective labor disputes, as well as disputes affecting the interests of third parties.

The experience of using mediation techniques has been shown to be effective in resolving various categories of disputes: labor, family, corporate, entrepreneurial conflicts, as well as disputes in the field of housing relations (Izmailov \& Baryshev, 2018). Undoubtedly, the mediation procedure has many advantages over the traditional, judicial way of resolving the conflict. So, the advantages of mediation include: reducing the time for resolving a dispute; reduction of expenses for the procedure; counterparty business reputation protection; full control over decisions made; the ability to maintain partnerships between the parties. In our opinion, the sphere of business and entrepreneurship has been and remains the most promising for the application of mediation. When a business conflict arises, the speed of resolving it is very important. In addition, it is often very important to maintain a relationship with the counterparty. Therefore, when resolving this kind of conflict, mechanisms are needed that will allow you to resolve the situation quickly and allow you to continue partnerships. Moreover, the outcome of the court decision is often unpredictable, therefore, the parties prefer to reserve the opportunity to control the outcome of the dispute and refer to the mediation procedure.

Article 3 of the Law on Mediation establishes the fundamental principles of the procedure: voluntariness, confidentiality, cooperation and equality of parties, impartiality, and independence of the mediator. In our opinion, the principle of privacy. The Mediation Act prohibits the mediator from disclosing information received from the parties to third parties, and also limits the possibility of one of the parties disclosing any information received individually from the other party without her consent. Additional guarantees of confidentiality are also contained in the norms of the procedural codes prohibiting interrogation of a mediator in court about circumstances that became known during the mediation process. These guarantees may be strengthened by a mediation agreement. The above favorably distinguishes the mediation procedure from other possible ways of resolving disputes.

The mediation procedure is carried out by a special subject - the mediator. Section 15 of the Law on Mediation contains requirements for a mediator. A mediator can carry out his activities on a professional and non-professional basis. An unprofessional mediator may be an adult, legally capable person who does not have a criminal record. A professional mediator can be a person who has reached the age of twenty-five, has a higher education and received additional professional education on the application of the mediation procedure. Introducing requirements for mediators, the state makes sure that qualified specialists come to the appropriate market - otherwise the very idea of alternative methods of dispute settlement can be discredited (Mikhailov, 2012). If the mediation procedure began after the dispute was submitted to the court or the court of arbitration, the mediator, in this case, can only be a person who carries out this activity on a professional basis. A mediator may not be a person replacing the posts of state civil or municipal service. In addition, by agreement of the parties or the rules approved by the organization providing the mediation procedure, additional requirements for the mediator may be established.

The principle of impartiality and independence is further enshrined in article 9 of the Law on Mediation, which determines that depending on the agreement reached, the parties independently choose one or more mediators or send an 
appeal to the organization that carries out activities to ensure the mediation procedure, so that it recommends or appoints intermediaries for dispute settlement. The status of mediators should be distinguished from the status of the organization providing the appropriate procedure. The first difference is that mediators are mediators in the settlement of the dispute, and organizations provide the process itself. The second difference is the material component of the issue. So, the organization carries out its activities only on a paid basis, mediators can provide services free of charge.

Mediators are individuals who carry out relevant activities on a professional or non-professional basis. In both cases, such activity is not entrepreneurial and does not require registration of a person as an individual entrepreneur.

An organization engaged in the provision of the mediation procedure is a legal entity, one of the main activities of which is the organization of the mediation procedure and must be registered in the manner prescribed by law. Mediation activities do not require a license or other permits. Self-regulation in the field of mediation is exclusively voluntary (Sungatullina et al., 2018).

The parties' agreement on the application of an alternative dispute resolution procedure is confirmed by an agreement concluded before or after the dispute in writing, expressed in including in the form of a mediation clause. In this case, the method of dispute settlement should be specified definitely and not be probabilistic in nature. If the case is referred to the court, mediation is a reason to postpone the case for up to 60 days.

In accordance with Article 2 of the Law on Mediation, the results of applying the mediation procedure are drawn up by a mediation agreement concluded in writing, which must contain information about: the parties; about the subject of the dispute; about the mediation procedure; about the mediator; obligations agreed upon by the parties, terms, and conditions for their implementation. If the mediation procedure was carried out after the dispute was submitted to the court or the arbitration court, the mediation agreement may be approved by the relevant court as a settlement.

The legislation provides guarantees for the execution of a mediation agreement by the parties. If the parties turned to the mediation procedure in a lawsuit, the mediation agreement is approved as a settlement. If the parties used mediation before filing an application with the court, a mediation agreement may be drawn up as a civil contract. A mediation agreement is a civil law transaction and violation of its terms by the parties may entail consequences provided for by the civil law Government for non-fulfillment or improper fulfillment of obligations, including termination of the agreement in court. A mediation agreement concluded as a result of mediation must be real, enforceable and legal. Settlement of the dispute through the mediation process, regardless of its results, does not detract from the rights of the parties to apply for judicial protection

Mediation is a special legal dispute resolution mechanism. At the same time, the mediator has no right to make a decision for the parties, to prompt and impose on the parties their position and vision of the situation, as this may lead to a violation of the basic principles of the procedure - neutrality and impartiality.

The mediation procedure becomes legal if the parties comply with the necessary formal requirements. The presence of the parties in a state of legal conflict justifies the need to follow the established rules and agreements reached both in the process of passing through the procedure, at its various stages and when making the final decision.

Since today the mediation procedure in Russia has not found its proper distribution and development, the issues of increasing the effectiveness and applicability of this procedure are constantly being discussed. It seems that the effectiveness of the legal regulation of entrepreneurial relations in any field depends on the effectiveness of legal norms aimed at achieving certain goals and meeting certain requirements (Mikhailov, 2014). In general, it can be said that the low applicability of the procedure is the result of many factors.

These are such factors as the inability of Russian society to quickly adapt to the emergence of new protection mechanisms, mistrust of any non-governmental institutions, the habit of going to court to resolve any conflicts and low court costs. It is most difficult to deal with such reasons for rejection of the new one since adaptation and mobility of society require years and marketing efforts to spread mediation. There are other factors related to the insufficiently perfect system of legislation on mediation and the lack of thought in some mechanisms. It seems easier to deal with these reasons; it does not take years and agitation in order to make the legislation more perfect.

\section{SUMMARY}

Our study of theoretical and practical problems of legal support of the mediation procedure in Russia and foreign countries allows us to draw the following conclusions:

1. Mediation is an effective way to resolve disputes, a special form of mediation with the participation of an independent person - a mediator, which does not involve a third party making a decision on the dispute.

2. The experience of using mediation techniques has been shown to be effective in resolving various categories of disputes: labor, family, corporate, business conflicts, as well as disputes in the field of housing relations. 
3. The effectiveness of the procedure for conducting the mediation procedure largely depends on the implementation at all stages (stages) of the basic principles: voluntariness, confidentiality, cooperation and equality of the parties, impartiality, and independence of the mediator.

4. It seems efficient and promising to use alternative methods of dispute resolution in general, and the use of mediation in particular. Using foreign experience and adapting it to the Russian system of law and society, you can get really significant results, simplicity, and speed of dispute resolution, confidentiality and the ability to maintain partnerships.

5. As one of the ways to improve the legislative regulation of mediation, the possibility of introducing a notarial certification of mediation agreements should be considered. Giving a mediation agreement with the power of a writ of execution will significantly increase the feasibility of the results of the procedure and increase the guarantees of execution. Also, it seems appropriate to apply mediation to disputes arising from administrative and other public relations.

\section{CONCLUSIONS}

Our study allows us to systematize knowledge about the mediation procedure as an alternative way to resolve disputes and to develop ways to improve the effectiveness of this procedure.

\section{ACKNOWLEDGMENTS}

The work is performed according to the Russian Government Program of Competitive Growth of Kazan Federal University.

\section{REFERENCES}

1. Types of Dispute Resolution Processes (2019). American Bar Association. [Electronic resource] Access mode URL: http://www.americanbar.org/groups/dispute_resolution/resources/DisputeResolutionProcesses.html free.

2. Alternative dispute resolution (ADR) (2019). Practical Law UK Glossary Thomson Reuters. [Electronic resource] Access mode URL: https://uk.practicallaw.thomsonreuters.com/0-107-6391 free.

3. Cadiet, L. (2011). Panorama des modes alternatifs de règlement des conflits en droit français. Ritsumeikan law review, 28, 147-167.

4. Abolonin, V. O. (2103). German law "On supporting mediation and other forms of out-of-court conflict resolution" (Mediations G) (with a brief explanation). Bulletin of the civil process, 5, 203 - 217.

5. Division of expertise and mediation (2019). [Electronic resource] Access mode URL: http://www.eurasiancommission.org/en/act/dmi/internal_market/Pages/default.aspx free. 06/07/2019.

6. Besemer, C. (2009). Mediation: die Kunst der Vermittlung in Konflikten. Werkstatt für Gewaltfreie Aktion, 233 p.

7. Izmailov, R., \& Baryshev, S. (2018). LEGAL PROBLEMS OF PROTECTION AGAINST UNFAIR COMPETITION IN THE SPHERE OF HOUSING AND COMMUNAL SERVICES. National Academy of Managerial Staff of Culture and Arts Herald, (1).

8. Mikhailov, A. V. (2012). To the question of methods of legal regulation of relations in the field of mediation. Development of mediation in Russia: theory, practice, education: collection of articles. - M.: Infotropic Media, 49-57

9. Sungatullina, L. A., Mikhaylov, A. V., \& Valeeva, A. V. (2018). Self-Regulatory Organizations in Russia and European Countries: Current State and Prospects of Development. HELIX, 8(1), $2214-2217$. https://doi.org/10.29042/2018-2214-2217

10. Mikhailov, A. V. (2014). The effectiveness of business law. Scientific notes of Kazan University of Humanitarian Sciences, 156, 86-95.

11. Riskin, L. L. (1985). The special place of mediation in alternative dispute processing. U. Fla. L. Rev., $37,19$.

12. Boulle, L., \& Rycrof, A. (1998). Mediation: principles, process, practice. JS Afr. L., 167.

13. Lieberman, J. K., \& Henry, J. F. (1986). Lessons from the alternative dispute resolution movement. The University of Chicago Law Review, 53(2), 424-439. https://doi.org/10.2307/1599646

14. Karjee, K. (2010). Alternative dispute resolution. Available at SSRN 1533355.

15. Liebmann, M. (2000). Mediation in context. Jessica Kingsley Publishers.

16. Bear, L. S. (1992). Alternative dispute resolution.

17. Gordon, R., Skeeters, M., Peek, L., \& Brookshier, D. (2002). U.S. Patent Application No. 09/895,675.

18. Edelman, P. B. (1984). Institutionalizing dispute resolution alternatives. Just. Sys. J., 9, 134.

19. Hensler, D. R. (2003). Our courts, ourselves: how the alternative dispute resolution movement is re-shaping our legal system. Penn St. L. Rev., 108, 165.

20. Candlin, C. N., \& Maley, Y. (1997). Intertextuality and interdiscursivity in the discourse of alternative dispute resolution. The construction of professional discourse, 201-222. 